ISSN 0258-7122

Bangladesh J. Agril. Res. 35(2) : 235-245, June 2010

\title{
CROP AGRICULTURE OF BANGLADESH: CHALLENGES AND OPPORTUNITIES
}

\author{
MOHAMMAD H. MONDAL ${ }^{1}$
}

\begin{abstract}
Crop agriculture in Bangladesh is constrained every year by challenges, such as a) Loss of Arabie Land, b) Population Growth, c) Climate Changes, d) Inadequate Management Practices, e) Unfair Price of Produces, and f) Insufficient Investment in Research. In Bangladesh, about 80,000 ha of arable land are going out of production every year. The loss is alarming and needs to be addressed immediately. The land use policy of the government should be updated and implemented immediately to stop further loss of arable land. Another problem to agriculture is the increase in the growth of population. The twin problem of arable land loss and population growth needs to be addressed simultaneously to ensure sustainable crop production. Country's crop production is also affected frequently by flood, drought, and salinity. Varieties/technologies tolerant to these natural hazards need to be developed. Renewable energy, reduction in the use of fossil fuels, and afforestation are recommended to mitigate the adverse effects of climate change. To sustain crop production, chemical fertilizers must be integrated with organic manure and costly non-urea fertilizers should continue to be subsidized. Incidence of pests and diseases has lately become severe due to climate change impacts. Therefore, more varieties resistant to the pests should be evolved. Small and marginal farmers of Bangladesh have limited access to institutional credit. They are not eligible for microcredit of NGOs either. Establishment of a new institution/foundation in line with PKSF is recommended to meet their needs. These farmers do not have farmers' associations or cooperatives to bargain for fair price of their produces. Government might encourage establishment of farmers' cooperatives to ensure fair price of their produces. To make such cooperatives successful, top-down approach by the influentials must be avoided. Investment in agricultural research should as well be raised to at least $2 \%$ of GDP to help generate technologies to cope with climate change hazards and disseminate such technologies at farmer's level.
\end{abstract}

Keywords: Crop agriculture, challenges and opportunities.

\section{Introduction}

Bangladesh economy draws its main strength from agriculture sector. The sector contributes $19.10 \%$ to GDP (at current prices) and employs $50.28 \%$ of the labour force. Despite increase in the shares of fisheries, livestock, and forestry, crop sub-sector alone accounts for 60.83\% share of agricultural GDP (BBS, 2008).

${ }^{1}$ Director General (Retd.), Bangladesh Agricultural Research Institute (BARI), Joydebpur, Gazipur, Bangladesh. 
Crop agriculture in Bangladesh is, however, constrained by a number of challenges every year. Major challenges include 1) Loss of Arable Land, 2) Population Growth, 3) Climate Changes, 4-6) Inadequate Management Practices (Fertilizer, Water, and Pests \& Diseases), 7) Lack of Quality Seeds, and 8-10) Inadequate Credit Support to Farmers, Unfair Price of Produces, and Insufficient Investment in Research. Bangladesh has lost about 1 million ha of arable land from 1983 to 1996. Virtually, no step has been taken by the government to arrest this loss. The land use policy prepared by the government several years back has not yet been implemented. Population growth poses another great threat to crop productivity. Besides, crop agriculture in Bangladesh has become regularly vulnerable to the hazards of climate change-flood, drought, salinity in particular. In addition, poor management practices, especially those of pests and diseases, fertilizer, water and irrigation have largely contributed to significant decline in crop productivity. Small and marginal farmers that constitute majority of farm population are constrained by poor financial resources and cannot, therefore, afford high management costs of high input technology.

Major objective of this review article is to discuss the challenges of crop agriculture of Bangladesh and suggest possible opportunities to address the issue that may assist the policy makers to develop policy guidelines.

\section{Challenges}

\section{Loss of arable land}

Bangladesh has lost about 1 million ha of productive arable land from 1983 to 1996 (BBS, 1999). That is about 80,000 ha of agricultural land per year are going out of crop production. Major factors responsible for land loss are urbanization, human settlement, building of infrastructure, and river erosion. The loss indeed is very alarming and therefore, needs to be addressed immediately. The government prepared a land use policy to stop this trend. But no step has so far been taken to arrest this diversion. Available statistics also indicates that about 1 million ha char lands are available in the country that could be used for growing crops like groundnut, sesame, mustard, maize, millets, etc. These productive lands are often occupied by the influentials who normally belong to political parties and administration. Recently, Honourable State Minster for Housing and Public Works declared to use khas lands for housing programme.

\section{Population growth}

Another major challenge to agriculture is the increase in the growth of population. Growth rate of population at present stands at 1.26\% (BER, 20082009). Population is increasing @ 2 million per year and the total population would be around 233 million by 2050 if the current growth rate continues. Such a growth rate of a country of $1,43,000 \mathrm{sq}$. $\mathrm{km}$ is viewed as a great challenge not 
only to different economic development activities but also as crisis to accommodation, environment and meeting other basic needs (food, education, and health). When the population growth demands more number of workers at field level, the number has considerably been reduced. Furthermore, birth control materials are not produced in the country and the supply is often inadequate compared to demands. Another major problem in population control lies with the religious fundamentalists. It may not be irrelevant to mention that different political parties are not interested to control population in the fear of losing vote banks of the fundamentalists.

\section{Climate change}

Atmospheric $\mathrm{CO}_{2}, \mathrm{CH}_{4}, \mathrm{SO}_{2}, \mathrm{~N}_{2} \mathrm{O}$, etc. are mainly responsible for temperature increase resulting in the rise of sea level. Temperature rise by $1.0^{\circ} \mathrm{C}$ would inundate $18 \%$ area of Bangladesh as indicated by different studies. At the same time, the country is affected frequently by flood, drought, cyclone, and salinity due to climate change. As a result, soil fertility, crop productivity, and food security would be seriously threatened. Climate change has also accelerated hunger, poverty, malnutrition and incidence of diseases, especially in developing countries (IPCC, 2007). It is basically the poor that would be worst victims of climate change. Profit driven mode of production by corporate agencies and their over extraction and consumption of fossil fuels (coal, oil) has also hastened global warming.

In Bangladesh, about 1 million ha of the coastal region is saline. But very few varieties are available for combating salinity. Drought affects annually 2.5 million ha in kharif and 1.2 million ha in dry season. Kharif drought affects T. aman rice severely. Besides, about $2.6 \mathrm{~m}$ ha are affected by flood in a normal year (Z. Karim, 1997). The devastating flood of 2004 inundated 40 districts and caused considerable loss of crops and human life. But very limited technologies are available that are tolerant to flood and drought.

According to Intergovernmental Panel on Climate Change (IPCC, 2001), coastal area of Bangladesh may go under saline water by 2050. Due to the rise in temperature, crop production will be reduced by about $30 \%$. Climate change, especially temperature rise would decrease the yield of boro rice by $55-62 \%$ and wheat by $61 \%$ by 2050 in Bangladesh (New Age, 2008). Frequent felling of green trees by the influentials, especially in coastal belts for building shipyards has also become a threat to climate change.

\section{Imbalanced use of fertilizers}

About $60 \%$ of arable lands of Bangladesh are deficient in N, P, and K. Organic matter content of soils is much below the critical level of 1.5\% (Z. Karim, 1997). 
Farmers normally use urea in recommended doses. Because of high prices, they apply $\mathrm{P}$ and $\mathrm{K}$ fertilizers at the rates that are far below the recommended amount. Chemical fertilizers are not normally integrated with organic manures. It is thus evident that farmers virtually do not use balanced fertilizers that are necessary for high productivity. A task force of the Ministry of Agriculture recently stated that the productivity of crops for the last few decades or so has either stagnated or declined even though fertilizer use in the country has almost increased three folds (G. Rahman, 2004).

\section{Inefficient water use}

Water use efficiency in Bangladesh is extremely low. On the average, 25-30\% of irrigation water is used by crops and the rest is lost due to faulty flood irrigation system (Z. Karim, 1997; M. Mondal, 2005). Conservation of rain water during monsoon is virtually non-existent that could be utilized for irrigating crops during dry season. Studies show that irrigation with surface water instead of underground water might reduce the vulnerability to hazards of climate change. Irrigation cost in Bangladesh is relatively high due mainly to high price of diesel. It is to be mentioned that more than $80 \%$ irrigation pumps in the country are diesel operated.

\section{Pests and diseases}

The use of fertilizers, quality seeds, and irrigation together can not ensure sustainable production unless timely and appropriate measures for the management of pests and diseases are simultaneously pursued. It is important to note that the incidence of diseases and pests has lately become very severe due to the adverse effects of climate change, particularly rise in temperature (IPCC, 2007). It is estimated that $4-14 \%$ of rice yield in Bangladesh is lost every year by different insect pests. Bacterial leaf blight (BLB) and nematode (ufra) are now the serious diseases in rice. But the technologies resistant to pests and diseases are still very limited. Use of $1 \mathrm{PM}$ technology is limited to rice and few vegetables.

\section{Lack of quality seeds}

Of the total seed requirement, only about $6 \%$ quality seeds were supplied in 2003-2004 (N. Huda et. al., 2004) although seed as an input could increase crop production by $10-15 \%$ (M. Mondal, 2005). Contribution of private sector and NGOs to quality seed production is still insignificant because they lack costly seed preservation and processing facilities. They have to depend on BADC for seed processing. It may be noted that farmer's low quality seeds still meet about 95\% seed requirement that is considered to be one of the major constraints to crop productivity. 


\section{Inadequate credit support to farmers}

About 90\% farmers of Bangladesh are small and marginal (below 2.5 acres). They are very often constrained by finance and thus cannot afford high cost for management. They have very limited access to institutional credit because of collateral requirement. At present, only $27 \%$ of farmers receive institutional credit (BBS, 2007). The credit amount again is quite inadequate and not advanced in time. They are also not eligible for microcredit of NGOs that deal mainly with landless farmers. The situation compels these farmers to apply inputs, especially expensive $\mathrm{P}$ and $\mathrm{K}$ fertilizers far below the recommended doses that finally result in low yield.

\section{Unfair price of agricultural produces}

Productive farmers of Bangladesh mainly belong to small and marginal categories. These farmers do not have either Farmer's Association or Farmer's Co-operative to bargain for fair prices of their produces. They are thus forced to sell their produces at low prices to intermediaries. Since the farmers are often unable to meet procurement requirements ( $14 \%$ moisture content, absence of foreign materials in seeds, etc.) of the government, they cannot sell their produces at the price fixed by the government.

\section{Insufficient investment in research}

Investment in agricultural research in Bangladesh now stands at only 0.20 of GDP (Z. Karim, 1997) even though agriculture contributes to $19.10 \%$ of GDP and employs $50.28 \%$ of labour force (BBS, 2008). Low investment has resulted in the underfunctioning of National Agricultural Research System (NARS). Scopes for promotion and training of potential scientists in different fields are also limited due mainly to fund constraint.

\section{Opportunities}

\section{Protection of arable land}

It is essential to review the present land use policy with the relevant experts, professionals, and farmers' representatives and update it based on their comments and suggestions. The policy should as well be enacted with immediate effect with the provision of regular monitoring and evaluation. The policy should also be put into operation immediately to stop further loss of arable land. Khas lands that are arable should not be diverted for housing as planned by the government. Such lands should be distributed to landless farmers and used exclusively for agricultural purposes. 


\section{Population control}

To arrest population growth, family planning services should be geared through field level workers and NGOs to reach all households across the country. More number of field workers needs to be deputed to provide such services. It is also necessary to produce enough birth control materials within the country to reduce dependence on import. The materials should be supplied in time to the field workers as per their requirement. It is heartening to note that the government is reactivating the family planning programme under "Strengthening Targetoriented Family Planning Project”. Ministries of Health \& Family Welfare and Finance are made responsible for implementing the project in line with the election pledge of the government.

It is highly imperative that the twin problem of arable land loss and population growth are addressed by the government simultaneously without any further delay to ensure increased and sustained production and thereby food security. Both the issues need to be categorically spelled out in the new National Agricultural Policy (NAP) under preparation by the Ministry of Agriculture.

\section{Adaptation/mitigation to climate change}

Bangladesh Rice Research Institute (BRRI) has developed BRRI dhan 40, 41, and 47 that are salt tolerant. The varieties should be introduced and disseminated in the area after necessary testing. More heat tolerant varieties of wheat need to be developed. CIMMYT and BARI may be urged to develop tropicalized wheat varieties. It is also necessary to use biotechnology or gene transfer technology to develop varieties tolerant to salinity, flood, and drought. There is also a need to develop HYVs in pulses, oilseeds, spices, and fruits since improved technologies in these areas are few. Country does not have its own supply of hybrid varieties of rice, vegetables, and other crops. In the circumstances, the government should urge BRRI, BARI, and other NARS institutes and private companies \& NGOs to develop their own hybrid variety programmes of these crops within the country. Climate change is a development issue and therefore, the change must be integrated into national development plan of the government. Besides, political commitment must be ensured to mitigate the problems- flood, sea level rise, and salinity intrusion of agricultural land in particular. It is emphasized that mitigation measures rather than adaptation practices may be considered as better solutions to the problem. Mitigation measures include the use of renewable energy, reduction, and efficiency in the use of fossil fuels, afforestation, early warning system to disaster management, preventing felling of green trees, especially in coastal areas, etc.

The Government of Bangladesh is yet to make an estimate on resources required to overcome climate change impacts. However, to implement "Climate 
Change Strategy and Action Plan 2009”, Ministry of Agriculture has recently estimated a demand of $\$ 5$ billion to address the problem for the next 5 years. Success of the plan largely depends on the commitment of the government since its implementation is dependent on several ministries. It is also extremely important that both Poverty Reduction Strategy Paper (PRSP-II) and Sixth Fiveyear Plan under formulation contain clear provisions to address the issue.

\section{Fertilizer management}

To encourage the use of balanced fertilizers, chemical fertilizers must be integrated with organic manures and subsidy benefit on non-urea fertilizers should continue. Farmers should gradually reduce their dependence on the use of chemical fertilizers to maintain soil fertility. It is essential that the government clearly spells out the need for balanced fertilizers in its new NAP in the interest of sustainable crop production. International Federation of Organic Agricultural Movement (IFOAM) has been in operation in 92 countries of the world including S. Korea, China, and Taiwan. Under the Movement, there are at present 527 members. Major objective of IFOAM is to create awareness among farmers about the need of organic matter in increasing soil fertility and crop productivity. It is proposed that Bangladesh becomes a member of IFOAM to motivate farmers to use organic fertilizers. It may be noted that the Prime Minister herself has laid emphasis on the increased use of compost fertilizers to boost crop production while the President of International Fertilizer Development Centre (IFDC) made a courtesy call on her recently.

\section{Water management}

For efficient use of water, irrigation should be applied at the appropriate growth stages of crops. Growing crops under minimum tillage, relay cropping and mixed cropping practices may also be strengthened for rainfed cropping. Farmers may be motivated to grow low- water requiring crops like pulses, wheat, etc. Different NGOs may as well be used to excavate derelict ponds, canals, etc. for the conservation of rain water for irrigation in dry seasons. It may be noted that there are a number of derelict ponds in Barind and other areas of the country. Rain water thus saved could be used for surface irrigation. Diesel price should be substantially cut to reduce irrigation cost or subsidized in the interest of resource poor small and marginal farmers.

\section{Pests management}

More resistant varieties should be developed using both conventional breeding and biotechnology to control the pests. It is also necessary to expand biotechnology and 1PM practice to other economic crops, such as oilseeds, pulses, spices, and fruits. The new NAP should as well emphasize the importance 
of the use of these environment-friendly frontier technologies. Recently, BARI has developed sex pheromone trap technology for the control of shoot and fruit borer in brinjals and cucurbits (S. Alam, 2008). To control bacterial wilt in brinjals, grafting technology on wild solanum has been also evolved by BARI (Ann. Rept, BARC, 2007-08). Attempts should now be made to transfer the technologies at field level.

\section{Quality seed production}

If the target of $20-25 \%$ of seed requirement is to be met, BADC's current seed production programme needs to be strengthened. To achieve this, present breeder's seed programme of NARS institutes should be expanded. Besides, private sector and NGOs are to be supported by the government for the production of quality seeds by providing credit on easy terms. Likewise, farmers need to be motivated to produce quality seeds. For this, they should be given massive training on seed production, preservation and processing. It is also important to support them through credit supply on easy terms and at low interest rate.

\section{Credit management}

The National Agricultural Policy (1999), Ministry of Agriculture proposed an institution named "Agricultural Credit Foundation" following the model of "Palli Karmo Sahayak Foundation” (PKSF). Major objective of the Foundation was to meet the demand for credit by marginal and small farmers. The Foundation was supposed to be established during the Fifth Five-Year Plan. Unfortunately, the institution has not been established even 8-9 years after the implementation of the national agricultural policy. Under the circumstances, a new such Institution/Foundation following the model of PKSF should be established along with necessary manpower and other facilities to cater to the needs of these farmers. They must have an access to the credit of the institution without any collateral requirement. The credit should be disbursed before planting time and realized at the end of the cropping season or after the harvest of the crops. The institution must have an in-built provision for strong monitoring unit to monitor the use of credit at regular intervals by its staff.

\section{Fair price of produces}

Government is urged to procure the produces directly from the farmers raising the present ceiling to at least $10 \%$ of the total production. Storage faculties may at the same time be established in rural areas following the experience of SHOGORIP that is likely to allow the farmers to store their produces and sell the same at better prices when the demand is high. Alternatively, government might encourage to establish farmers' cooperatives to ensure fair price of their 
produces. To make the cooperatives successful, traditional top-down approach must be avoided. The cooperatives should not be run as a commercial profitmaking entity. Formation of "Agricultural Prices Commission" by the government is also suggested for fixing the prices of farmers' produces.

\section{Return to research investment}

Different studies indicate that the investment in agricultural research is highly rewarding and beneficial (M. Miah et al., 2005; J. Nagy et al., 2000). The Government is, therefore, urged to raise the investment to at least 2\% of GDP as recommended by World Bank and FAO (FAO, 1996; Strat. Plan, 1995). The increased investment will certainly encourage scientists to develop technologies to cope with the hazards of climate change and disseminate the same at farmer's level.

\section{Recommendations}

- It is essential to review the present land use policy with the relevant experts, professionals, and farmer's representatives and update it based on their comments and suggestions. The policy should be enacted and put into operation immediately to stop further loss of arable land. Khas lands that are arable should not be diverted for housing.

- It is highly imperative that the twin problem of arable land loss and population growth is addressed by the government simultaneously to ensure production sustainability and food security. Both the issues need to be categorically spelled out in the new National Agricultural Policy (NAP) under preparation by the Ministry of Agriculture.

- The government should urge BRRI, BARI, and other NARS institutes, private companies and NGOs to develop their own hybrid variety programmes of rice, vegetables and other crops within the country.

- Strong political commitment must be ensured to implement the present "Climate Change Strategy and Action Plan". It is also extremely important that both Poverty Reduction Strategy Paper (PRSP-II) and Sixth Fiver-Year Plan under preparation contain clear provisions to address the issue.

- To encourage the use of balanced fertilizers, chemical fertilizers must be integrated with organic manures. The government should clearly spell out the need for balanced fertilizers in its new NAP in the interest of sustainable production. Farmers should as well be motivated to reduce their dependence on the use of chemical fertilizers to maintain soil fertility. 
- Irrigation should be applied at the appropriate growth stages of crops for efficient use of water. Growing crops under minimum tillage, relay cropping and mixed cropping practices may also be strengthened for rainfed farming. Farmers may be motivated to grow low-water requiring crops like pulses, wheat, etc. Different NGOs may as well be used to excavate derelict ponds, canals, etc. for the conservation of rain water for irrigation in dry seasons.

- It is also necessary to expand biotechnology and 1PM practice to other economic crops, such as oilseeds, pulses, spices, and fruits for the management of pests and diseases. The new NAP should emphasize the importance of the use of these environment-friendly frontier technologies in pest management.

- Farmers' low quality seeds still meet about 95\% seed requirement. For quality seed production, they should be given massive training on seed production, preservation, and processing. It is also important to support them through credit supply on easy terms and at low interest rate.

- A new institution/foundation following the model of Palli Karmo Sahayak Foundation (PKSF) should be established along with necessary manpower and other facilities to cater to the needs of resource-poor marginal and small farmers. The institution must have an in-built provision for strong monitoring unit to monitor the use of credit at regular intervals.

- Storage facilities may be established in rural areas following the experience of SHOGORIP that may allow farmers to store their produces and sell the same at better prices. Alternatively, the government might encourage to establish farmers' cooperatives to ensure fair price of their produces. The cooperatives should not, however, be run as a commercial profit-making entity.

- Since investment in agricultural research is highly rewarding and beneficial, the government should raise the investment to at least $2 \%$ of GDP as recommended by World Bank and FAO. The increased investment will certainly encourage scientists to develop technologies to cope with the hazards of climate change.

\section{References}

Bangladesh Economic Review (BER). 2009. Economic Division, Ministry of Finance.

Executive Summary. 2007-2008. Annual Report, Bangladesh Agricultural Research Council (BARC).

Golam Rahman. 2004. Windows of Agriculture in Bangladesh. 
Intergovernmental Panel on Climate Change (IPCC). 2007. Impacts, adaptation and vulnerability. Report of the working group-II.

M. A. M. Miah, et. al. 2005. Returns to investment on research and extension of high yielding winter tomatoes in Bangladesh. Bangladesh J. Agril. Research 30 (4): 538545.

M. Nurul Alam et. al. 2005. Development and Management of improved technology in increasing productivity challenges and opportunity of agriculture in 21st century. Agricultural Employees Conference and Technology Fair. Ministry of Agriculture.

Mohammad H. Mondal. 2005. Challenges and Opportunities of sustainable crop production in Bangladesh. Eighth Biennial Agronomy Convention. Bangladesh Society of Agronomy.

Nagy, J. G. et. al. 2000. Impact of agriculture research in Bangladesh, estimating returns to agricultural research. Bangladesh Agricultural Research Management Project (ARMP), BARC and IFDC.

National Agricultural Policy. 1999. Ministry of Agriculture (GOB).

Nazmul Huda et. al. 2004. National Seed Management. Agricultural Employees Conference and Technology Fair. Ministry of Agriculture.

Statistical Yearbook of Bangladesh. 1999. Bangladesh Bureau of Statistics (BBS).

Statistical Yearbook of Bangladesh. 2007. Bangladesh Bureau of Statistics (BBS).

Statistical Yearbook of Bangladesh. 2008. Bangladesh Bureau of Statistics (BBS).

Strategic Plan for National Agricultural Research System (NARS) to the year 2010 and beyond. 1995.

Syed Nural Alam et. al. 2008. Control of pests and diseases in vegetables through integrated pest management. Agricultural Technology Manual. BARI.

Technical Background Document of World Food Summit. 1996. FAO.

The New Age. June 2008.

Z. Karim. 1997. Accelerated Agricultural Growth in Bangladesh. Seminar on Agricultural Research on Development in Bangladesh. BARC. 